\title{
SISTEM KUARANTIN DAN PELAKSANAANNYA DI TANAH MELAYU PADA SEKITAR ABAD KE-19
}

\author{
Aiza Maslan @ Baharudin
}

\begin{abstract}
The implementation of quarantine has long left its imprints in the history of human civilization. Contagious diseases such as cholera and measles often claim a large number of victims. Thus, the earliest medical problem to become the concern of more than one government was the problem of preventing epidemics spreading from one country to another. Between the 14th and 19th century, many countries around the world already applied several methods of quarantine as a means to protect their citizens from falling victim to epidemics. The first and natural reaction of a threatened community was an attempt to isolate itself against the advancing danger. The provision for quarantines was introduced in Malaya by the British in 1858. Beginning September 1868, new quarantine ordinances were imposed on all ships utilising ports in the Straits Settlements. The quarantine provisions in Malaya did not only involve foreign labourers, but also the pilgrims who were returning from Mecca. From isolation to mass migration out of affected geographical areas, the citizens of Malaya applied various traditional methods in their effort to curb the spread of epidemics. Various signals were put up in order to prevent entry into the affected zones. Nevertheless, the implementation of quarantines in Malaya were at times difficult to execute following the lack of full cooperation from the local citizen.
\end{abstract}

\section{Pengenalan}

Sejak ribuan tahun dahulu penularan wabak penyakit berjangkit seperti kolera, bubon dan malaria sering menimbulkan kebimbangan kepada masyarakat dunia kerana kemunculannya sering menelan jumlah 
korban yang besar. Perkembangan tamadun manusia telah menjadikan masalah berkenaan semakin serius apabila manusia mula melibatkan diri dalam pelbagai aktiviti yang memerlukan mereka bergerak dari satu kawasan ke satu kawasan yang lain. Manusia sering menjadi ejen utama penyebaran wabak penyakit berjangkit khususnya apabila mereka berhubungan dengan populasi yang tidak mempunyai sebarang bentuk imunisasi terhadap sesuatu penyakit. Sejarah telah membuktikan bahawa wabak penyakit berjangkit boleh membawa kesan yang begitu serius sehingga menggugat kestabilan dan seterusnya menyumbang kepada keruntuhan sesebuah tamadun.

Sebelum pertengahan abad ke-19, persoalan kesihatan dan pengkajian tentang penularan wabak penyakit kurang diberi perhatian di peringkat antarabangsa. Namun begitu, setelah berlakunya beberapa siri serangan wabak penyakit ke Eropah yang mencatatkan jumlah korban yang besar penularan wabak penyakit berjangkit mula menjadi topik perbincangan antarabangsa. Persidangan Kesihatan Antarabangsa kali ketujuh di Venice pada tahun 1892 yang dihadiri oleh 14 buah negara yang diadakan secara khusus bagi membincangkan tentang isu penularan wabak kolera telah memperkenalkan langkah-langkah kawalan kesihatan antarabangsa yang bertujuan melindungi Eropah daripada serangan wabak penyakit, antaranya ialah mewajibkan sistem kuarantin terhadap kapalkapal. Walau bagaimanapun, kaedah kuarantin sebagai satu langkah pengawalan penularan wabak penyakit berjangkit sebenarnya bukanlah satu konsep baru kerana banyak negara di dunia yang telah mengaplikasikannya ribuan tahun lebih awal mengikut kaedah tersendiri.

\section{Reaksi Masyarakat terhadap Penularan Wabak Penyakit}

Suatu ketika dahulu, jangkitan wabak penyakit berjangkit sering ditanggapi sebagai balasan dan hukuman daripada Tuhan ke atas kesalahan dan kesilapan yang dilakukan oleh manusia di muka bumi. Justeru, tidak banyak perkara yang boleh dilakukan bagi mengelak dan menghalang penularannya kecuali dengan mengadakan upacara sembahyang dan penyembahan pengorbanan kepada Tuhan. Akhbar The Times pernah melaporkan bahawa pada tahun 1947, ketika wabak kolera menyerang Mesir, terdapat segelintir masyarakat yang mengadakan upacara menggunting ruangan udara menggunakan gunting kayu besar dengan kepercayaan bahawa tindakan berkenaan dapat mengelakkan sebarang bentuk penularan wabak penyakit. ${ }^{1}$

Apabila pandangan yang lebih rasional mula mendapat tempat dalam kalangan masyarakat, mereka mula menyedari bahawa 
kemasukan individu dan barangan dari kawasan atau wilayah yang dijangkiti wabak penyakit ke kawasan lain boleh menyebabkan penularan wabak berkenaan. Pelbagai langkah telah digunapakai bagi mengatasi penularan wabak penyakit berjangkit. Antara kaedah yang agak keras adalah usaha negara dan komuniti menghalang kemasukan individu dan barangan daripada kawasan atau wilayah yang diserang wabak atau menghalang individu keluar daripada wilayah yang dijangkiti. Usaha pengasingan tersebut kadangkala dilakukan secara lebih serius sehingga melibatkan penguatkuasaan enakmen kehakiman dan kekuatan ketenteraan. ${ }^{2}$ Sekatan seumpama ini kemudiannya dikenali sebagai kuarantin yang berasal daripada perkataan Itali 'quaranta' yang bermaksud 40 hari tempoh pengasingan. ${ }^{3}$

\section{Sejarah Awal Kuarantin}

Sepanjang abad ke-19, usaha menghalang penyebaran wabak penyakit berjangkit tertumpu kepada isu kuarantin. ${ }^{4}$ Kaedah kuarantin sebenarnya telah lama diaplikasikan yang bermula dengan pengasingan pesakit kusta. Namun begitu, langkah kuarantin antarabangsa yang melibatkan kaedah pengasingan individu dan barangan bagi suatu tempoh yang tertentu yang ditetapkan hanya diinstitusikan buat pertama kalinya pada abad ke-14 apabila wabak bubon $^{5}$ atau dikenali sebagai The Black Death mengancam Eropah. Kaedah pengasingan seumpama ini pernah diaplikasikan oleh beberapa buah negara di dunia dan dilakukan sewenang-wenangnya tanpa mempunyai sebarang garis panduan:

\footnotetext{
It has been suggested, however, that the Knights Hospitallers of the Order of St. John of Jerusalem first adopted a forty-day quarantine after their establishment on the island of Rhodes in 1306. The Republic of Ragusa (now Dubrovnik) is a third claimant, with some justice, to the priority of introducing quarantine in 1377 . There the period of quarantine was thirty days at first, and only later forty and this might be extended to fifty days in winter to prolong the action of the sun - a most modern conception. (By 1797, quarantine at Marseilles varied from eighteen to fifty days, according to the state of the Bill of Health, type of cargo and port of departure). ${ }^{6}$
}

Pusat kuarantin (lazaretto) yang pertama dalam sejarah telah ditubuhkan di Santa Maria, Nazareth, Venice pada tahun 1423 yang dikenali sebagai 'The Nazarethum'. Sistem Venetian tersebut yang diperkenalkan khusus bagi menghalang penularan wabak bubon kemudiannya telah mendapat perhatian seluruh Eropah dan model kod lengkap peraturan 
kuarantin yang digubal oleh pihak penguat kuasa Venice pada tahun 1448 telah diguna pakai selama 400 tahun oleh negara-negara lain termasuk Genoa (1526), Marseilles (1526), England (1585), Scotland (1564) dan Perancis (1683).?

Antara abad ke-14 hingga ke-19, banyak negara di dunia telahpun mengaplikasi beberapa kaedah kuarantin bagi melindungi rakyat mereka daripada jangkitan wabak penyakit. Antara langkah kuarantin yang utama adalah dengan mengenakan tempoh pengasingan bagi kapal, anak kapal dan barangan yang datang dari pelabuhan asing yang disyaki ditulari wabak penyakit berjangkit, terutamanya bubon, demam kuning dan kolera. Bagi mengelak daripada dikenakan prosedur kuarantin, pemilik kapal harus mengemukakan dokumen rasmi (clean bill of health) yang mengesahkan bahawa pelabuhan terakhir yang disinggahi oleh kapal terbabit bebas daripada sebarang bentuk serangan wabak penyakit berjangkit. Penggunaan dokumen seumpama ini telah diperkenalkan pada tahun 1527 tetapi mula digunakan secara meluas sejak tahun $1665 .^{8}$

Dr. Richard Mead (1673-1754), seorang pakar perubatan pernah mengeluarkan nasihat kepada Kerajaan British berhubung isu kuarantin yang diterbitkan pada awal abad ke-18 di dalam 'A Short Discourse concerning Pestilence Contagion and the Methods to be used to Prevent it' dan terbitan berkenaan mendapat edaran secara meluas sehingga ke peringkat antarabangsa. Antara lain beliau menyentuh:

\begin{abstract}
Near to our several Ports, there should be Lazarettos built in convenient Places, on little Islands if it can so be, for the Reception both of Men and Goods, which arrive from Places suspected of Infection: the keeping Men in Quarantine on board the Ship being not sufficient; ... If there has been any Contagious Distemper in the Ship; the Sound Men should leave their Cloaths; which should be burnt; the Men washed and shaved; and having fresh Cloaths, should stay in the Lazaretto thirty or forty days...The Sick, if there be any, should be kept in Houses remote from the Sound; and some time after they are well, should also be washed and shaved, and have fresh Cloaths; whatever they wore while Sick being burnt: And then being removed to the House of the Sound, should continue there thirty or forty days. ${ }^{9}$
\end{abstract}

Kaedah kuarantin pada zaman pertengahan merupakan ritual yang pelik tetapi amat mengagumkan. Umpamanya, langkah berjagajaga pernah diambil terhadap sebuah kapal Catalian yang berlabuh di Palermo yang membawa seramai 97 orang termasuk 18 orang penumpang. Tiga orang kelasi dan dua orang penumpang dilaporkan meninggal dunia akibat serangan wabak penyakit yang tidak 
diketahui sewaktu kapal berkenaan berlabuh untuk mengambil muatan iaitu ikan masin, gula, keju masin, garam dan sejumlah bandela kain. Akibat daripada peristiwa berkenaan, pemilik kapal dikehendaki mengemukakan sejumlah wang yang ditetapkan sebagai jaminan bahawa kapal berkenaan tidak akan meninggalkan pelabuhan sehingga diberi 'pratique' atau kebenaran. Kemudi diambil daripada kapal dan pengawasan ketat telah dijalankan terhadap kapal terbabit. Semua yang berada di dalam kapal terbabit, melainkan pesakit dan seorang kelasi telah dihantar ke darat, iaitu 'Borgo'. ${ }^{10}$

Di 'Borgo' semua pakaian mereka dilucutkan, diwapkan dengan bahan hitam yang dibuat daripada arang batu, turpentin dan petroleum dan dibilas dengan cuka. Sesetengah pakaian dibakar dan yang lainnya dibasuh, dianginkan dan diharumkan selama 50 hari. Pesakit telah dihantar ke 'lazaretto', iaitu 'The Cuba', sebuah bangunan batu yang besar di Palermo yang kini merupakan sebuah monumen sejarah kuarantin terawal. Muatan kapal turut ditangani dengan ketelitian yang sama. Tong ikan masin dibersihkan dengan air laut dan dibilas dengan cuka. Guni gula dan pembalut keju masin dibakar. Barangbarangan lain dianginkan dan diharumkan selama 50 hari. Manakala, pakaian tidak dilipat sebaliknya digantung di tiang-tiang layar bagi tempoh yang sama. Kain layar dan tali-temali kapal diturunkan, direndam ke dalam laut selama seminggu dan digantung di tiang layar sepanjang tempoh kuarantin. Pengasapan di dalam kapal dilakukan dengan mendidihkan bahan hitam diperbuat daripada arang batu, turpentin dan petroleum di antara dek-dek kapal. Tempoh 50 hari ditetapkan menggantikan 40 hari atas alasan musim sejuk pada waktu itu. ${ }^{11}$

Bagi kuarantin di darat, sebagaimana dilakukan di Naples pada tahun 1577, semua orang diperiksa tahap kesihatan di pintu-pintu masuk kota. Para pengawal diarah berjalan kaki dan menunggang kuda di sekeliling kota bagi memastikan tiada sebarang pencerobohan secara sulit dilakukan. Penyata kesihatan yang dilengkapi dengan cop mohor menyatakan bahawa negara asal pelancong, tarikh dan waktu bertolak telah diwajibkan. Penyata kebersihan yang mengiringi barangan dagangan turut diwajibkan. Namun begitu, pada waktu serangan wabak yang serius semua barangan muatan kecuali rempahratus dan ubat-ubatan akan diragui tahap keselamatannya. ${ }^{12}$

Selain itu, pada tahun 1720, usaha telah dilakukan bagi menghalang penularan wabak bubon dari Marseilles dengan menempatkan sekumpulan pengawal bagi mengepung kawasan yang dijangkiti wabak penyakit dan mereka diarahkan supaya melakukan rondaan sepanjang malam. Hukuman dan ancaman keras dikenakan terhadap sesiapa sahaja yang cuba melarikan diri dari kawasan 
kepungan terbabit sehingga melibatkan tindakan memecahkan kepala sebagai amaran kepada yang lain:

...if anyone escaped he was to be chased, captured, taken back to the spot from which he had escaped and have his head broken in the presence of his neighbours as an example to them...if any physician or surgeon wished to leave because he was afraid, and feelings or religion and honour did not restrain him, he was to be detained by force, with a treat to break his skull. ${ }^{13}$

Amalan kuarantin juga pernah diadakan di Mina sebagaimana yang dicatatkan oleh Mirza Mohammad Hosayn Farahani, ${ }^{14}$ seorang jemaah haji Iran berfahaman Shiah berdasarkan pengalaman yang disaksikan oleh beliau sendiri semasa mengerjakan ibadah haji pada tahun 1885. Menurutnya, pada setiap hari sepanjang tempoh tiga hari melontar jumrah, pegawai perubatan Daulah Uthmaniyah akan menerima satu senarai daripada pihak pengurusan jenazah bagi mengenal pasti jumlah dan punca kematian. Sekiranya kematian disebabkan oleh wabak penyakit berjangkit, Istanbul dan pos kawalan di sempadan akan dimaklumkan. Mesyuarat pegawai penguat kuasa kesihatan awam di Istanbul akan menetapkan tempat dan tempoh kuarantin yang perlu dilaksanakan. Sehelai bendera kuning akan dikibarkan di atas gunung menandakan terdapatnya serangan penyakit berjangkit. Bendera berkenaan sering menimbulkan ketakutan dalam kalangan jemaah haji. Namun begitu, langkah kuarantin berkenaan tidak selalunya menjanjikan kejayaan sebagaimana yang berlaku semasa musim haji tahun 1893. Seramai hampir 33,000 orang jemaah haji meninggal dunia akibat serangan wabak kolera pada tahun tersebut. ${ }^{15}$

Menjelang awal abad ke-19, penyokong langkah kurantin berpandangan bahawa langkah berkenaan sangat berkesan dalam membendung penularan wabak penyakit berjangkit dan harus diteruskan, sebaliknya satu pihak lagi menyifatkan langkah kuarantin sebagai 'the game was not worth the candle'. Langkah kuarantin disifatkan mereka sebagai menjengkelkan, menindas dan kejam. Akta Kuarantin Inggeris 1710 umpamanya, memperuntukkan agar kapal yang belayar tanpa lesen dirampas daripada pemiliknya dan diserahkan kepada pihak Queen. Pemilik kapal berkenaan akan didakwa sebagai penjenayah atas pelbagai kesalahan kuarantin. Pada tahun 1813, Antonio Bong ditembak mati di Malta atas kesalahan merahsiakan wabak penyakit yang menjangkiti beliau. Akta Kuarantin England 1825 juga menetapkan hukuman mati bagi mereka yang berhubungan dengan kapal yang dikuarantin. ${ }^{16} 10$ tahun kemudian, Sir Richard Mead 
menyokong bahawa 'if a Ship come from any place, where the Plague raged, at the time of the Ship's Departure from it, with more than usual Violence, it will be the securest method to Burn all the Goods, and even the Ship'. ${ }^{17}$

\section{Pelaksanaan Kuarantin di Tanah Melayu}

Sehingga abad ke-19, negeri-negeri di Tanah Melayu terutamanya di kawasan bandar disifatkan sebagai sesak dan kotor berikutan pertambahan penduduk berlaku begitu pesat. Pertumbuhan penduduk di Pulau Pinang dan Province Wellesly umpamanya, meningkat daripada 133,230 orang kepada 247,808 orang antara tahun 1871 sehingga tahun 1901. Melaka juga menyaksikan peningkatan jumlah penduduk daripada 77,756 orang kepada 95,487 orang pada tempoh yang sama. Manakala, di Perak peningkatan penduduk adalah daripada 214,254 orang pada tahun 1891 kepada 329,665 orang pada tahun 1901. Peningkatan yang besar juga dapat dilihat di Selangor iaitu daripada 81,592 orang pada tahun 1891 kepada 168,789 orang pada tahun $1901 .^{18}$ Keadaan tersebut mempercepatkan proses penularan wabak penyakit berjangkit terutamanya di kawasankawasan yang terkepung seperti penjara, hospital dan pusat tahanan orang gila. Seorang Pegawai Perubatan Kuala Lumpur pada tahun 1882 pernah menyifatkan tahap kesihatan penduduk sebagai "a very unsatisfactory state'due to the 'notoriously dirty and filthy state of the town and the habits of the people', impure water, and drought leading to an outbreak of'choleric diarrhoea'...". 19

Pada peringkat awal, pentadbiran British di Tanah Melayu sebelum akhir abad ke-19 menunjukkan kecenderungan untuk tidak campur tangan dan mengeluarkan peruntukan yang besar dalam menangani hal ehwal persekitaran dan kebersihan dalam negeri. Walau bagaimanapun, kebimbangan terhadap reputasi pentadbiran British berikutan kadar kematian yang tinggi pada setiap tahun dalam kalangan penduduk Tanah Melayu yang merangkumi golongan dewasa dan kanak-kanak akhirnya telah mendorong perubahan sikap dan polisi Kerajaan British. Tekanan dan desakan dari Britain yang menghantar perwakilan dari Dewan Perniagaan bersama Ronald Ross dari Liverpool School of Tropical Medicine and Hygiene akhirnya telah membawa kepada penubuhan sebuah suruhanjaya yang dipertanggungjawab memeriksa dan mengemukakan laporan tentang tahap kebersihan di Tanah Jajahan. ${ }^{20}$

Berikutan penubuhan suruhanjaya berkenaan, Lembaga Kebersihan telah diwujudkan di kawasan penempatan penduduk dan di peringkat negeri yang bertanggungjawab tentang pelupusan najis dan sampah-sarap, pembaikan longkang dan tandas awam, 
penyahjangkitan rumah penduduk dan penutupan telaga yang tidak digunakan. Lembaga berkenaan turut diberi kuasa menjalankan pemeriksaan dan mendakwa mereka yang gagal mematuhi peraturan kesihatan dan kebersihan awam antaranya gagal mendaftar perniagaan hasil tenusu, memiliki kedai dobi tanpa lesen dan memiliki premis yang terlalu kotor dan sesak. Selain itu, Pegawai Kesihatan dengan kerjasama Lembaga berkenaan juga bertanggungjawab terhadap keadaan kebersihan jalan raya, pengeluaran lesen kepada premis perniagaan dan kilang, pendaftaran kenderaan awam seperti jinrikisha dan penyahjangkitan bangunan semasa berlakunya penularan wabak penyakit. Bangunan yang dianggap membahayakan kesihatan awam diarah untuk dirobohkan di bawah peruntukan Enakmen Kuarantin dan Pencegahan Penyakit 1903. ${ }^{21}$

Peruntukan kuarantin juga telah diperkenalkan di Tanah Melayu oleh pihak British dalam tahun 1858 di bawah Native Passenger Act, namun peruntukan tersebut dianggap tidak lengkap oleh Conférence Sanitaire International yang berlangsung di Konstantinople pada bulan Ogos 1866. Ordinan kuarantin yang baru kemudiannya telah diperkenalkan pada September 1868 yang diwajibkan ke atas semua kapal yang menggunakan pelabuhan Negeri-negeri Selat termasuk kapal yang membawa jemaah haji. Ordinan berkenaan turut memperkenalkan peraturan bagi memastikan kebersihan di atas kapal dititikberatkan dan mewujud kan mekanisme bagi mengawasi sebarang bentuk penularan wabak penyakit di atas kapal. Jawatankuasa Pembentungan Singapura juga pernah mengemukakan permohonan agar pemeriksaan kesihatan dijalankan terhadap setiap kapal yang tiba di pelabuhan Singapura. Kaedah kuarantin juga turut dicadangkan bagi setiap penumpang yang dijangkiti penyakit dan denda dikenakan terhadap kapten kapal yang membenarkan penumpang yang sakit turun dari kapal terbabit. Walau bagaimanapun, peruntukan berkenaan telah mendapat tentangan daripada The Straits Settlements Association ${ }^{22}$ yang dianggotai oleh golongan pedagang dan pemaju yang merasa bimbang bahawa penggubalan undang-undang berkenaan akan merencatkan pertumbuhan perdagangan..$^{23}$ Menurut mereka, langkah tersebut memerlukan Kerajaan Negeri-negeri Selat mengeluarkan perbelanjaan yang besar sedangkan keberkesanannya disifatkan oleh mereka sebagai belum terjamin. ${ }^{24}$ Perkara seumpama ini sememangnya dijangkakan berdasarkan pandangan yang pernah dikemukakan oleh Setiausaha Tanah Jajahan:

The Singapore Colonial Secretary shared the view of ships' officer that quarantine was 'a fight in the dark', and cancelled regulations that prevented boats with cholera cases on board from anchoring 
in local harbours, leading to outrage from some residents who claimed that this showed the most sublime and callous indifference to the well-being of (the) colony and an insulting contempt for (the) discretion of the local authorities. ${ }^{25}$

The Straits Settlements Association kemudiannya telah bertindak melobi Gabenor Negeri-negeri Selat agar ordinan berkenaan dibatalkan dengan mengemukakan beberapa alasan. Antaranya ialah masyarakat Hindu, Cina dan Melayu yang sangat menitikberatkan tentang kaedah pelupusan mayat setiap individu, campur tangan pihak British dianggap mencerobohi hak privasi individu dan kawalan yang dilakukan terhadap kapal tidak akan dapat membendung penularan wabak penyakit berjangkit seperti kolera. ${ }^{26}$ Bantahan terhadap keberkesanan sistem kuarantin yang berterusan di peringkat tempatan dan antarabangsa telah mendorong Ketua Pegawai Kesihatan Negerinegeri Selat mengadakan lawatan pada tahun 1912 ke Jawa, Australia, South Afrika, Siberia dan Jepun bagi meneliti dan mengkaji keadaan tahap kesihatan dan pelaksanaan kuarantin di negara-negara terbabit. Laporan yang dikemukakan oleh beliau akhirnya membawa kepada penubuhan sebuah biro di Singapura yang bertanggungjawab mengumpul dan menyebarkan maklumat berhubung jangkitan wabak penyakit di pelabuhan dan negeri rantau ini. ${ }^{27}$

Peruntukan kuarantin juga turut melibatkan golongan buruh asing yang dibawa masuk ke Tanah Melayu sejak tahun 1860-an berikutan desakan keperluan terhadap tenaga buruh sebagai susulan daripada perkembangan sektor perladangan getah dan perlombongan pada ketika itu. Penghijrahan buruh India dan Cina secara besarbesaran telah menyumbang kepada peningkatan jumlah penduduk pada ketika itu. Malah, penghijrahan buruh India dan Cina juga mewujudkan permasalahan kesihatan yang serius di Tanah Melayu. Kebanyakan buruh asing dibawa masuk dari selatan India sebagai pekerja estet. Undang-undang yang diperkenalkan pada tahun 1877 dan diubahsuai pada tahun 1885 secara langsung membenarkan ejenejen berlesen yang dikenali sebagai Kangani dihantar ke India bagi mencari tenaga buruh. Melalui Sistem Kangani, majikan yang ingin mendapat buruh dari India akan menghantar seorang Kangani dari estetnya ke India untuk mendapatkan buruh dari kampung halaman Kangani berkenaan. Buruh-buruh yang dipilih akan dibawa ke kem Kangani di Madras atau Negapatam, India bagi menjalani pemeriksaan kesihatan sebelum dibawa ke Tanah Melayu. Setiap Kangani akan dibayar mengikut bilangan pekerja yang diambil dan pekerja tersebut juga seharusnya bertanggungjawab untuk membayar tambang dan perbelanjaan lain bagi buruh berkenaan sehingga ketibaan mereka di 
ladang. Tenaga buruh yang dibawa pulang kemudiannya ditempatkan di pusat-pusat kuarantin sama ada di Pelabuhan Swettenham, Selangor atau di Pulau Pinang selama tiga minggu sebelum dihantar ke estet yang akan mengupah mereka. ${ }^{28}$

Kemasukan buruh asing dari China ke Tanah Melayu juga dipantau oleh rang undang-undang yang digubal oleh Majlis Perundangan Negeri-negeri Selat bagi memastikan bahawa tahap kesihatan buruh asing terbabit berada dalam keadaan yang baik sebelum dibawa ke Tanah Melayu. Penularan wabak bubon di Hong Kong dan beberapa pelabuhan di China sejak tahun 1894 yang dikhuatiri menular ke Tanah Melayu dan kesukaran Konsul British di pelabuhan-pelabuhan di China memastikan sama ada buruh asing yang dibawa sihat atau sebaliknya mendorong pihak British memperuntukkan bahawa buruh Cina hanya dibenarkan dibawa ke Tanah Melayu menggunakan kapal milik British. Perkara tersebut dikuatkuasakan ekoran kesulitan mengawal selia tahap kesihatan buruh Cina di atas kapal asing kerana ketiadaan kemudahan pegawai perubatan. ${ }^{29}$

Peruntukan kuarantin terhadap buruh asing sangat penting dalam mengenal pasti penyakit yang berisiko tinggi yang dibawa oleh golongan buruh asing, sekali gus membolehkan tindakan segera diambil bagi membendung penularannya kerana pengambilan buruh asing sering mengundang permasalahan kesihatan terhadap masyarakat tempatan. Permasalahan kesihatan yang melibatkan buruh asing seumpama ini dilaporkan pernah berlaku di Papua New Guinea. ${ }^{30}$ Menurut J. Norman Parmer:

British rule first made the incidence of disease and death very
much worst than before. The clearing of land for estates, the
expansion of mining and the construction of public works
disturbed existing ecological balances, causing disease to spread
and multiply. The large immigrant labour forces assembled for
these capital investments lacked natural immune systems. The
colonial government, the chief provider of medical services, also
lacked experience and knowledge and as a consequence many
tens of thousands of workers died.

Semasa ditahan di pusat kuarantin, pada kebiasaannya hanya sebilangan kecil buruh-buruh berkenaan yang dihantar pulang ke India kerana permasalahan kesihatan. Sebahagian besarnya diberi rawatan semasa dalam kuarantin, terutamanya mereka yang mempunyai masalah cacing kerawit, walaupun kesemua buruh kontrak berkenaan telah pun diberi antihelminthics, iaitu sejenis dadah yang membunuh 
cacing kerawit sebelum mereka dibawa ke Tanah Melayu. ${ }^{32}$ Seksyen 24, Bahagian IV, Enakmen Imigrasi Buruh India Selangor, 1884 (Selangor Indian Immigration Enactment, 1884) telah menyediakan garis panduan yang mesti dipatuhi oleh pelbagai pihak yang bertanggungjawab merekrut buruh asing dari India:

Any such Immigrant found on examination to be unfit for labour from diseases or physical debility shall be sent to a hospital for a medical treatment, and shall be detained there till declared by the Medical Officer in charge of the hospital to be fit for labour, when he shall be handed over to the Indian Immigration Agent for detention in a depot under the preceeding section, or if he be a Statute Immigrant to his employer, and if the Immigrant is declared to be incurable or permanently unfit for labour under a contract under this Enactment he shall be sent back at the expense of the employer by whom or on whose behalf the advances have been made to the place at which he was recruited in India. ${ }^{33}$

Buruh asing yang gagal mematuhi arahan yang diperuntukkan, iaitu menjalani pemeriksaan di pusat kuarantin sebagaimana yang telah ditetapkan akan dikenakan denda tidak melebihi 50 ringgit atau penjara tidak melebihi tiga bulan. ${ }^{34}$ Walau bagaimanapun, peruntukan kuarantin terhadap buruh asing tidak menampakkan kesan yang membanggakan kerana estet sering mencatatkan jumlah kematian pekerja buruh yang tinggi. Di sesetengah kawasan, hampir separuh daripada pekerja buruh estet meninggal dunia dalam tempoh setahun sejak kedatangan mereka ke Tanah Melayu. Perkara tersebut adalah disebabkan oleh gaya hidup buruh asing yang tidak mementingkan tahap kesihatan dan kebersihan.

...(t)he cooly cares little or nothing about cleanliness or ordinary sanitary precautions, and Tamil labourers were reputed to be poorly nourished because of strict dietary regulations, preference for toddy (distilled palm wine or other alcohol) over food, 'stinting' on food, and the alleged disinclination of unmarried men to cook for themselves or employ a cook. Further, the selection of labourers was not well supervised. While emigration officers denied that selection procedures were remiss, immigration workers were often sick on arrival... A 1900 account also described arriving labourers as emaciated , 'famine stricken', and 'old decrepit men who should never have been allowed through the depot in India'. ${ }^{35}$

Melalui pengalaman, masyarakat di Tanah Melayu mendapati bahawa kuarantin berjaya mengekang penularan wabak penyakit berjangkit daripada terus merebak dengan cepat. Sudah menjadi 
kebiasaan bagi masyarakat di Tanah Melayu, apabila seseorang individu diserang wabak penyakit berjangkit, seperti cacar seluruh kampung akan mengasing dan memulaukan individu terbabit. Sebagai contoh, pada tahun 1891, virus cacar yang dilaporkan di daerah Kuala Kangsar telah disebarkan oleh seorang jemaah haji yang baru kembali dari Tanah Suci. Dalam satu lagi kes yang berlaku di Daerah Matang, Taiping, Perak pada tahun 1897, penyakit cacar juga telah menjangkiti seorang jemaah haji yang menyebabkan beliau dipulau dan diasingkan oleh penduduk kampung. Laporan mengenai jangkitan berkenaan hanya dibuat empat hari kemudian atas kelalaian Penghulu Mukim terbabit. ${ }^{36}$

Sekiranya wabak penyakit berjangkit telah menular di dalam sesebuah kampung, penduduk kampung terbabit akan melarikan diri dari kampung terbabit, sekali gus menyebabkan penyakit berkenaan tersebar lebih jauh. Peristiwa perpindahan beramai-ramai dari kawasan yang diserang wabak penyakit bukanlah perkara asing dalam kehidupan masyarakat Melayu pada abad ke-19. J. R. Logan umpamanya, semasa lawatannya ke Kedah dalam tahun 1850 telah terserempak dengan seorang pemerintah dan pengiringnya di muara Sungai Kedah yang meninggalkan kawasannya yang dilanda wabak cacar. ${ }^{37}$ Wabak cacar juga dikatakan pernah menyerang pahlawan Pahang, Tok Gajah. Setelah dijangkiti cacar, beliau meninggalkan pasukannya dan menyerahkan kuasa kepada Haji Muhammad Nor dan Penghulu Chenor. Setibanya di Pahang, beliau tidak menghadap Bendahara kerana bimbang akan menyebarkan virus berkenaan. ${ }^{38}$ Apabila Birch tiba di Perak pada bulan November 1874, beliau mendapati Sultan Abdullah telah mudik ke hulu meninggalkan Batak Rabit juga akibat serangan cacar. ${ }^{39}$ Raja Jalor dan pengikutnya turut berpindah akibat serangan penyakit yang sama. Tuanku Boosah dari Daerah Muar juga dilaporkan mengambil langkah yang sama meninggalkan kawasannya kerana takutkan jangkitan cacar. ${ }^{40}$

W. W. Skeat juga mencatatkan pengalaman beliau menghadiri pengkebumian seorang lelaki Kelantan yang menjadi korban cacar. Jenazah lelaki berkenaan dikebumikan sebatu dari kawasan kampung di kawasan anak sungai (charuk) berdekatan pohon sampang. Adalah dipercayai bahawa sejak turun-temurun bahawa tiada siapa yang berani mendekati pohon tersebut kerana getahnya sangat beracun dan menyebabkan kemerahan, kesakitan dan kegatalan. Baju yang dipakai oleh mangsa cacar akan dibakar bersama rumahnya. Di Jelebu, penduduk kampung dikecualikan daripada menghadiri upacara pengebumian sekiranya kematian adalah disebabkan oleh cacar. Roh mangsa cacar dan kolera, seperti mana roh mangsa pembunuhan bukan 
sahaja sangat ditakuti oleh orang Melayu, tetapi juga oleh masyarakat Cina. Semasa lawatan Hugh Low ke Kuala Kurau beliau berkesempatan melihat masyarakat nelayan Cina yang mendiami 40 buah rumah berlari-lari membawa bendera yang dikatakan bertujuan mententeramkan roh jahat yang disebabkan oleh kolera. ${ }^{41}$

Serangan wabak kolera sangat ditakuti oleh masyarakat di Tanah Melayu kerana serangan wabak berkenaan sering mengundang jumlah korban yang sangat besar. E. W. Birch, Majisret dan Pemungut Hasil Tanah di Melaka pernah mencatatkan tentang peristiwa serangan wabak kolera:

We had a terrible cholera epidemic in Malacca. It was a worrying time in which Dr. J. T. Leask worked indefatigably, often sleeping half-dressed ready to answer a night summons. Mr Copley of the Municipality and an Inspector of Police gave splendid assistance. Between the four of us, the entire Town was inspected every day sulphur fires were kept burning at most street corners, all who were sick with the scourge were removed to a segregation hospital, three Police Constables who drove the hospital ghari died. Everyone begged for the corpses of their relatives to be handed to them for burial and necessary refusal was very distasteful... ${ }^{42}$

John D. Gimlette, ketika bertugas sebagai seorang pakar bedah di Kelantan pernah mengemukakan nasihat serta cadangan agar penyahjangkitan di kawasan yang dicemari najis dan muntah pesakit kolera dilakukan menggunakan asid karbolik. Beliau turut menyarankan agar bahan kumbuhan dan mayat manusia dikebumikan di kawasan kering yang jauh daripada kawasan tadahan air. Tempoh kuarantin yang dicadangkan bagi pesakit yang diserang kolera ialah selama tujuh hari. Peruntukan yang dikemukakan oleh Gimlette dan arahan terhadap penghulu dan pegawai-pegawai Kerajaan Kelantan berhubung penyahjangkitan kuman, penjagaan pesakit dan pelupusan mayat kemudiannya dikeluarkan dalam bentuk pekeliling dan diedarkan secara meluas. ${ }^{43}$

Bagi orang Melayu, terdapat isyarat khusus yang menjadi kebiasaan mereka untuk menandakan kawasan pengasingan atau kuarantin. Thomas Braddell (1823"1891), ${ }^{44}$ dalam lawatannya ke Segamat, Johor pada awal tahun 1850-an telah bertemu dengan sebuah kawasan kuarantin, iaitu seutas tali diregang di antara dua batang kayu dan beberapa helai daun atau 'putchoh' 45 digantung di atas tali berkenaan. Isyarat berkenaan menandakan larangan memasuki kawasan terbabit berikutan serangan cacar ke atas 30\% penduduk Muar. ${ }^{46}$ Satu lagi kaedah kuarantin yang digunakan pada sekitar tahun 1899 di Biserat, selatan Thailand ialah mengepung kawasan rumah 
yang dijangkiti penyakit dengan rotan bini atau dini yang diikat dari batang ke batang dengan benang Jawa yang dipintal. Terdapat juga 'a rope of jungle grass similarly arranged with pendant slipknots of coconut fronds, the rope and threads being fastened in the middle'. Di setiap pintu masuk rumah yang dikepung ditanam dua batang pokok bedara pahit (surycoma latifolia) secara menyilang. Kuarantin selama 10 hari telah diarahkan oleh seorang bomoh DiRaja tempatan. Tiada siapa dibenarkan melintasi garisan tersebut. Denda sebanyak $\$ 5.00$ dikenakan bagi sesiapa yang melanggar perintah. Setiap rumah mesti membayar 5 kenderi, iaitu 15 sen Singapura sebagai upah upacara kuarantin tersebut. Di Kelantan, cara yang sama digunakan untuk mengepung seluruh kampung. Kepahitan pohon berkenaan dipercayai dapat menghalau semangat jahat disebabkan oleh cacar. ${ }^{47}$

Satu lagi cara yang sering digunakan di Tanah Melayu ialah pesakit dikuarantin di rumah sendiri dan dikawal oleh seorang pengawal di luar rumah bagi mengelakkan sebarang bentuk komunikasi dengan orang lain. Tindakan seumpama ini pernah dilakukan terhadap seorang wanita Melayu yang tinggal di kawasan Parit Buntar, Perak. Usaha pihak berkuasa untuk menjalankan proses penyahjangkitan terhadap penduduk kampung yang telah berhubungan dengan wanita terbabit menemui jalan buntu setelah ditentang oleh penduduk kampung. Dalam dua kes berasingan usaha pihak berkuasa untuk membakar rumah mangsa yang dijangkiti wabak penyakit turut menemui jalan buntu apabila pihak polis gagal menyekat kemaraan penduduk kampung yang bersenjatakan keris, kayu, kapak dan senjata tajam yang lain. Tindakan penduduk kampung telah menyebabkan sepasukan askar bantuan seramai 50 orang lengkap bersenjata ditempatkan sementara di kawasan terbabit di bawah pengawasan Kapten Lamprey bagi mengundurkan orang kampung dan memudahkan kerja pembersihan dijalankan. ${ }^{48}$

Gimlette juga pernah mengingatkan pegawai-pegawai Eropah yang bertugas di Tanah Melayu agar tidak sewenang-wenangnya membakar kediaman pesakit dengan mengemukakan alasan bahawa masyarakat tidak seharusnya dibiarkan panik sehingga mendorong mereka lari bertempiaran dan membawa bersama mereka penyakit yang membahayakan. Memandangkan kebanyakan orang Melayu pada peringkat awal tidak mempunyai kepercayaan penuh terhadap hospital yang ditubuhkan oleh pihak kerajaan, Gimlette berpendapat bahawa pengasingan pesakit yang dijangkiti wabak harus dilakukan di sebuah rumah yang terasing daripada masyarakat umum. Langkah terbaik untuk mendapat kerjasama daripada masyarakat setempat menurut beliau adalah dengan menanamkan rasa keyakinan dalam kalangan masyarakat tempatan dengan membiarkan proses pengkebumian 
pesakit berlangsung tanpa sebarang gangguan, menggalakkan masyarakat menghantar kuali dan peralatan memasak untuk dikukus di rumah yang diasingkan dan menyokong amalan masyarakat menggunakan perkhidmatan pawang dan bomoh. ${ }^{49}$

Pada tahun 1877, Hugh Low, Residen British di Perak pada tahun 1877"1889 pernah mengarahkan agar pesakit cacar di Kampung Buaya, Perak $^{50}$ dikumpulkan di dalam sebuah rumah dan diasingkan. Pesakit akan dijaga oleh mereka yang telah sembuh daripada penyakit berkenaan. Hugh Low juga pernah mencadangkan agar pesakit dibawa ke hospital tentera untuk rawatan lanjut. Namun begitu, ketakutan terhadap jangkitan cacar turut menyebabkan keengganan pegawai perubatan memeriksa pesakit. Hugh Low akhirnya mengarahkan agar sebuah hospital khusus bagi penyakit cacar didirikan di Daerah Matang yang beroperasi selama empat setengah hari seminggu. Pembinaannya menelan belanja sebanyak $\$ 80.00$ ke $\$ 90.00 .{ }^{51}$ Penghuni rumah yang dijangkiti wabak penyakit berjangkit mesti melaporkannya di balai polis berdekatan. Ketua Polis mesti memaklumkan perkara tersebut kepada pegawai penguatkuasa kesihatan dengan seberapa segera yang boleh. Beliau juga boleh mengemukakan perintah bertulis daripada Mahkamah Majistret bagi memindahkan pesakit ke hospital yang diperuntukkan. Bilik dan rumah pesakit mesti menjalani proses nyahjangkitan kuman dan ditutup tidak melebihi tujuh hari sejurus selepas dikosongkan. Penghulu Mukim harus mengambil langkah segera mencegah sesiapa sahaja daripada memasuki atau meninggalkan rumah yang dijangkiti dengan arahan bertulis daripada Jabatan Kesihatan. Laporan juga harus dibuat di balai polis berdekatan dan di Mahkamah Majistret Daerah. ${ }^{52}$

Penghulu bertanggungjawab mengarahkan dengan seberapa segera pembinaan pagar sejauh $50 \mathrm{kaki}$ di sekeliling rumah yang dijangkiti dan rumah berkenaan diletakkan di bawah pengawasan pihak polis. Penghulu juga bertanggungjawab memastikan makanan dan air mencukupi disediakan dan kosnya ditanggung oleh pesakit dengan berhutang kepada Kerajaan Negeri Perak. Bekalan makanan mesti diletakkan pada jarak 100 ela dari rumah yang dikuarantin dengan arahan pegawai penguat kuasa kesihatan dan diberi kepada penghuninya dengan bantuan daripada pihak polis. Sekiranya berlaku kes baru di kawasan berkenaan, semua penghuninya akan dipindahkan ke rumah yang telah dipagar. Rumah yang baru dijangkiti dibasmi kuman atau dimusnahkan mengikut arahan. Sekiranya rumah yang telah dipagar tidak mampu menampung penghuni baru, rumah yang baru dijangkiti akan dipagar dan termaktub kepada peraturan yang sama seperti rumah sebelumnya. ${ }^{53}$ Katil, pakaian dan barangan lain milik pesakit hendaklah dimusnahkan atau dibasmi kuman. Membakar 
baju mangsa penyakit berjangkit merupakan kaedah yang sering digunakan. Di Gapis, Perak, pakaian mangsa cacar yang telah sembuh turut dibakar dan mereka diberikan pakaian baru. ${ }^{54}$

Melalui Enakmen Kuarantin dan Pencegahan Penyakit 1903, Seksyen 3, telah ditetapkan bahawa setiap kali berlakunya penularan wabak penyakit berjangkit tempat-tempat awam seperti restoran, teater, panggung wayang dan dewan orang ramai mesti ditutup bagi mengurangi risiko penularan wabak yang semakin serius. Kedai-kedai menjual todi di sesetengah estet juga ditutup bagi mengelakkan sebarang bentuk perhimpunan awam. Pegawai-pegawai kerajaan juga kadangkala diberi kuasa mengenakan kuarantin terhadap individu yang dijangkiti wabak penyakit berjangkit, terutamanya semasa berlakunya penularan wabak kolera, cacar, bubon dan disentri. ${ }^{55}$ Penularan wabak influenza di Tanah Melayu pada September 1918 menelan jumlah korban yang besar dan antara yang terjejas teruk akibat penularan wabak berkenaan ialah institusi pendidikan. Sehubungan dengan itu, Kolej Melayu Kuala Kangsar telah ditutup pada 13 Oktober tahun yang sama berikutan jangkitan wabak terhadap 135 orang pelajarnya. Kebanyakan sekolah-sekolah lain juga ditutup menjelang pertengahan bulan Oktober. Kemudahan hospital yang ada tidak mampu menampung kemasukan pesakit yang terlalu ramai sehingga menyebabkan panggung wayang turut digunakan sebagai hospital sementara. ${ }^{56}$

\section{Sistem Kuarantin dan Ibadah Haji}

Sebelum pertengahan abad ke-19, persoalan kesihatan yang melibatkan jemaah haji tidak diberikan perhatian yang serius selain isu kapal haji yang penuh sesak dan jemaah haji yang terkandas di Hejaz. Pengkajian tentang penularan wabak penyakit juga kurang dilakukan. Namun begitu, setelah beberapa siri serangan wabak penyakit ke Eropah yang menelan korban yang besar dikaitkan dengan ibadah haji, peranan ibadah haji sebagai agen penularan wabak penyakit berjangkit mula menjadi topik perbincangan antarabangsa sekali gus membawa kepada campur tangan kuasa-kuasa Eropah dalam hal ehwal haji umat Islam. Persidangan Kesihatan Antarabangsa kali ketujuh di Venice pada tahun 1892 yang dihadiri oleh 14 buah negara telah diadakan secara khusus bagi membincangkan tentang isu penularan wabak kolera yang berpunca daripada pengerjaan ibadah haji umat Islam. Persidangan berkenaan telah memperkenalkan langkah kawalan kesihatan yang bertujuan melindungi Eropah daripada serangan wabak penyakit, antaranya mewajibkan sistem kuarantin ke atas kapal yang membawa jemaah haji. Sejak itu, isu kawalan kesihatan dan prosedur kuarantin 
berhubung ibadah haji terletak di bawah pengawalan antarabangsa. Pulau Kamaran yang terletak di bahagian selatan Laut Merah di pertengahan jalan di antara Loheiya dan Hodeidah telah dipilih sebagai pusat kuarantin bagi kapal haji yang datang dari arah selatan dan mula beroperasi buat pertama kalinya pada tahun 1882 dengan kehadiran 9,067 orang jemaah haji. ${ }^{57}$ Setiap kapal haji dari Tanah Melayu diwajibkan berhenti di Pulau Kamaran dan hanya dibenarkan meninggalkan pusat berkenaan setelah pemeriksaan kesihatan dilakukan. ${ }^{58}$

Mulai Januari 1896, peraturan kuarantin yang dibuat oleh Daulah Uthmaniyah telah disiarkan di dalam Warta Kerajaan Negeri-negeri Melayu Bersekutu untuk pengetahuan umum. Sekiranya berlaku serangan wabak penyakit di Makkah, masyarakat umum akan dimaklumkan dan jemaah haji akan diberi peringatan. Jemaah haji yang kembali dari Tanah Suci Makkah juga tidak dibenarkan pulang ke tanah air tanpa menjalani langkah kuarantin yang tegas dan teliti. Maklumat tentang kapal-kapal dari Jeddah yang berkemungkinan perlu menjalani kuarantin diberikan lebih awal. ${ }^{59}$ Langkah tersebut diambil kerana wabak penyakit seperti cacar, bubon dan kolera yang sangat ditakuti oleh orang Melayu sering dibawa balik ke Tanah Melayu oleh jemaah haji. Penularan wabak bubon di Tanah Suci Makkah pada tahun 1897 telah diumumkan di dalam Warta Kerajaan Perak yang antara lain menyebut bahawa jemaah haji Tanah Melayu tidak dibenarkan pulang ke tanah air tanpa terlebih dahulu menjalani peraturan kuarantin yang ketat. ${ }^{60}$

Pada tahun 1897, satu peraturan khas telah dikeluarkan oleh Jabatan Kesihatan Awam Daulah Uthmaniyah. Kapal yang menuju Hejaz dan membawa jemaah haji tidak lebih dari seorang bagi setiap 100 tan yang didaftarkan tidak dikira sebagai kapal haji. Kapal yang membawa jemaah haji tidak melebihi lima orang bagi setiap 100 tan yang didaftarkan akan dikategorikan sebagai kapal haji dan dibenarkan meneruskan pelayaran ke pusat kuarantin Abu Saad, Jeddah dan menjalani kuarantin di sana.$^{61}$ Kapal haji pula dibahagikan kepada tiga kategori, iaitu kapal bebas penyakit, kapal disyaki dan kapal dijangkiti. Kapal bebas penyakit adalah kapal dari pelabuhan yang bebas penyakit, tidak sesak dan tiada sebarang kes penyakit yang mencurigakan di atas kapal, seperti kolera, bubon dan demam kuning sebelum bertolak, semasa pelayaran dan setibanya di pelabuhan. Kapal tersebut dibahagikan kepada dua kategori: kategori pertama ialah kapal dari pelabuhan di Laut Merah, Mesir dan pelabuhan di utara Terusan Suez dan kategori kedua ialah kapal dari Teluk Parsi dan Zanzibar. Kapal kategori pertama diberikan kebenaran meneruskan pelayaran selepas 
menjalani pemeriksaan kesihatan dan kapal kategori kedua akan ditahan selama 24 jam dan jemaah haji diturunkan di pusat kuarantin bagi menjalani pemeriksaan kesihatan dan penyahjangkitan kuman. ${ }^{62}$

Kapal yang disyaki pula adalah kapal yang sesak yang datangnya dari Tanah Melayu, Sri Lanka dan Hindia Timur Belanda. Mereka dikenakan kuarantin selama lima hari dan pakaian serta barangan mereka akan menjalani proses penyahjangkitan kuman. Sekiranya terdapat penumpang kapal yang dijangkiti kolera mereka akan menjalani proses yang sama seperti kapal yang dijangkiti. Kapal yang dijangkiti pula dibahagikan kepada dua kategori. Kategori pertama ialah kapal dari pelabuhan yang dijangkiti kolera atau bubon, tetapi tiada sebarang jangkitan di atas kapal. Kapal dan penumpang akan dibasmi kuman dan dikuarantin selama 10 hari. Kategoi kedua ialah kapal yang mempunyai kes kolera dan bubon di atas kapal. Kapal dari India termasuk dalam kategori kedua. Penumpang yang menghidap kolera atau bubon dihantar ke hospital yang dikhususkan bagi penyakit berjangkit. ${ }^{63}$

Jemaah haji yang lain diasingkan mengikut kumpulan dan setiap satunya mengandungi beberapa orang sahaja bagi memudahkan pengasingan kumpulan yang dijangkiti. Pakaian, barangan dan kapal akan dibasmi kuman. Air kotor di dalam kapal akan disedut keluar dan air minuman akan digantikan dengan yang baru. Kapal dan jemaah haji akan menjalani tempoh 15 hari kuarantin secara berasingan. Kumpulan yang dijangkiti kolera atau bubon akan menjalani semula 15 hari kuarantin dikira dari tempoh pengasingan mereka dari pesakit yang dijangkiti. Pesakit yang pulih dari jangkitan akan menjalani 15 hari kuarantin. Tempoh kuarantin akan dibaharui setiap kali kes baru dikesan. Jemaah haji India dan Tanah Melayu yang melalui Suez untuk ke Jeddah mesti melalui kuarantin melainkan mereka berjaya membuktikan melalui pasport dan dokumen rasmi bahawa mereka datang dari negara yang bebas jangkitan di utara Suez dan menetap di Mesir dalam keadaan sihat sekurang-kurangnya 10 hari. Kapal yang mengambil penumpang India dan Tanah Melayu di Suez dan tidak memenuhi perkara tersebut akan dianggap sebagai kapal yang dijangkiti dan akan terus dihantar ke Pusat Kuarantin Kamaran. ${ }^{64}$ Jemaah haji akan dikuarantin selama lima hari bagi kes kolera dan enam hari bagi kes bubon. Sekiranya berlaku kes baru, tempoh kuarantin ditambah lima hari lagi bagi kolera dan enam hari bagi bubon dari tarikh pengasingan terakhir. Setelah tamat tempoh kuarantin jemaah haji dibenarkan menaiki kapal menuju Jeddah. Kapal berkenaan akan sekali lagi menjalani pemeriksaan kesihatan di Jeddah. ${ }^{.5}$

Pada tahun 1922, Jawatankuasa Pejabat Kesihatan Antarabangsa teiah mengadakan perbincangan berhubung penggunaan mesej dan 
isyarat kuarantin dengan menggunakan bendera dan lampu ${ }^{66}$ Sebuah model mesej yang akan dihantar oleh kapal kepada pihak berkuasa pelabuhan tidak kurang dari empat jam dan tidak lebih dari 12 jam sebelum tiba di mana-mana pelabuhan telah dicadangkan bagi memudahkan urusan kuarantin. Mesej tersebut mestilah mengandungi beberapa maklumat penting berikut: 1) Nama kapal, tarikh dan waktu berlepas 2) Bilangan penumpang, anak kapal dan jumlah penumpang yang akan mendarat di pelabuhan berkenaan 3) Pelabuhan berlepas 4) Nama dan penjelasan mengenai penyakit berjangkit yang berlaku di atas kapal sepanjang pelayaran 5) Jumlah kes dan penjelasan mengenai keadaan setiap kes 6) Nama dan penjelasan mengenai penyakit lain selain daripada yang disebutkan di nombor $5 .{ }^{67}$

Jawatankuasa berkenaan turut mencadangkan penggunaan bendera $Q$ pada siang hari dan lampu hijau di atas lampu putih pada malam hari bagi menunjukkan kapal berkenaan bebas penyakit dan memerlukan kebenaran belayar. Bagi kapal yang disyaki dua buah bendera $Q$ digunakan pada siang hari dan lampu putih di atas lampu hijau pada malam hari. ${ }^{68}$ Bendera $F(L)$ pada siang hari dan lampu merah di atas lampu hijau pada waktu malam menunjukkan kapal berkenaan dijangkiti penyakit. Persidangan Radio dan Telegraf Antarabangsa Washington 1927 telah meluluskan isyarat bagi waktu siang tetapi menolak isyarat pada waktu malam kerana boleh mengelirukan banyak pihak dan mengundang bahaya. Hanya isyarat lampu merah di atas lampu putih dibenarkan pada waktu malam yang menunjukkan kapal tersebut tidak mendapat kebenaran belayar. Penggunaan mesej dan isyarat yang seragam tersebut hanya berkuat kuasa selepas 1 Januari $1934 .{ }^{69}$ Langkah seumpama ini pernah dikuatkuasakan oleh Kerajaan Perak yang mana kesemua kapal yang datang dari pelabuhan yang dijangkiti wabak penyakit berjangkit akan dikuarantin. Pemilik kapal berkenaan dikehendaki menaikkan bendera kuarantin berwarna kuning di kepala tiang layar utama beserta kod di bawahnya di waktu siang. Pada malam hari, lampu merah dipasang lebih tinggi daripada lampu hijau di tiang layar utama. Jarak di antara kedua-duanya mestilah tidak kurang dari empat kaki dan tidak lebih dari enam kaki. Kesemua bot pengawal dipasang bendera kuarantin yang sama berwarna kuning di buritan di waktu siang dan memasang lampu di hadapan dan di buritan pada waktu malam. ${ }^{70}$

Pada sekitar tahun 1930-an dan 1940-an, jemaah haji yang pulang dari mengerjakan ibadah haji menggunakan kapal laut akan dikuarantin di Pulau Jerejak sebelum dibenarkan turun di pelabuhan Pulau Pinang atas arahan daripada pihak Lembaga Kesihatan Pelabuhan Pulau Pinang sebagai langkah berjaga-jaga terhadap sebarang penularan 
wabak penyakit berjangkit. Tindakan tersebut telah membangkitkan rasa tidak puas hati dalam kalangan jemaah haji kerana mereka telahpun mendapat suntikan vaksinasi sebelum bertolak ke Tanah Suci Makkah. Rungutan juga timbul berikutan masa yang diambil untuk memindahkan jemaah haji dari kapal ke motorbot dan kemudiannya ke Pulau Jerejak memakan masa yang agak lama sehingga menyebabkan jemaah haji terpaksa berpanas tanpa sebarang perlindungan. Terdapat juga kes yang mana jemaah haji terjatuh ke dalam laut sewaktu operasi berkenaan dijalankan. Selain daripada itu, kemudahan yang disediakan di pulau berkenaan juga tidak mencukupi. ${ }^{71}$ Menurut Hajah Umi Kulsom, salah seorang jemaah haji yang menunaikan ibadah haji pada tahun 1936 jemaah haji pada kebiasaannya ditahan di pulau berkenaan selama dua hingga tiga jam dan mereka dikehendaki menanggalkan pakaian mereka untuk dikukus. Sekiranya terdapat sebarang kes jangkitan penyakit, jemaah haji akan ditahan di pulau berkenaan lebih lama. ${ }^{72}$

\section{Kesimpulan}

Kaedah kuarantin sangat penting dalam usaha mencegah penularan wabak penyakit seperti cacar dan kolera yang amat ditakuti oleh masyarakat. Pelbagai kaedah tradisional telah diaplikasi oleh masyarakat di Tanah Melayu dalam usaha membendung penularan wabak penyakit, daripada pemulauan dan pengasingan pesakit sehinggalah kepada perpindahan beramai-ramai penduduk dari kawasan yang diserang wabak. Memandangkan masyarakat Melayu sering menolak untuk dimasukkan ke hospital kerajaan, langkah terbaik yang dilakukan adalah menjadikan sebuah rumah di kawasan yang terbabit sebagai pusat kuarantin bagi mereka yang dijangkiti wabak penyakit berjangkit. Walau bagaimanapun, usaha pengawalan penyakit di Tanah Melayu kadang kala sukar dilaksanakan berikutan kegagalan mendapat kerjasama sepenuhnya daripada masyarakat setempat. Bagi mengatasi kesukaran menangani penentangan masyarakat, kerjasama daripada pelbagai pihak termasuk Mahkamah Majistret, polis dan penghulu kampong terpaksa digunakan bagi menjayakan operasi kuarantin yang dijalankan.

\section{Nota}

Neville M. Goodman, International Health Organizations, London: Churchill Livingstone, 1971, hlm. 27.

Ibid., hlm. 28.

Ibid., hlm. 28 dan R. Hood, "Defeat of Pestilence Foreshadows End of Quarantine", World Health, Vol. 12, No. 1, 1959", hlm. 20. 
4 Mary Byrne McDonnell, The Conduct of Hajj from Malaysia and Its SocioEconomic Impact on Malay Society: A Descriptive and Analytical Study, 1860-1981, PhD Dissertation, Columbia University, 1986, hlm. 36.

5 Bubon merupakan sejenis wabak yang melemahkan sistem limfa disebabkan oleh sejenis bakteria, iaitu Yersinia pestis. Ia merebak akibat gigitan pinjal atau kutu yang telah dijangkiti yang pada kebiasaannya menghinggapi binatang kecil bergigi tajam, seperti tikus dan tupai. Simtom bubon biasanya ialah bengkak pada nodus limfa, terutamanya di bawah ketiak, celah kangkang dan leher, tompok merah yang kemudiannya bertukar hitam pada kulit, kesukaran bernafas, muntah darah berterusan dan kesakitan pada anggota badan. Wabak ini biasanya boleh membunuh kira-kira 50\% mangsa yang dijangkiti dalam masa 4-7 hari.

Lihat Neville M. Goodman, International Health Organizations, hlm. 31. Lihat R. Hood, "Defeat of Pestilence", hlm. 20.

Lihat Neville M. Goodman, International Health Organizations, hlm. 31. Ibid., hlm. 32.

10 Lihat R. Hood, "Defeat of Pestilence", hlm. 20.

11 Ibid., hlm. 20.

12 Ibid., hlm. 28.

$13 \quad$ Neville M. Goodman, International Health Organizations, hlm. 28.

14 Mirza Mohammad Hosayn Farahani meninggalkan manuskrip bertajuk Safarnameh of Mirza Mohammad Hosayn Farahani yang mengandungi catatan perjalanan dan pengerjaan haji ke Tanah Suci Makkah yang dibuat dalam tahun 1885. Manuskrip berkenaan telah diedit dan diterjemahkan ke dalam bahasa Inggeris, iaitu Farahani, A Shiite Pilgrimage: The journey of an Iranian Notable to the Holy Cities of Arabia through Iran, Russia, the Ottoman Empire and Egypt, Austin: University of Texas Press, 1990.

15 Lihat F. E. Peters, The Hajj: The Muslim Pilgrimage to Mecca and The Holy Places, New Jersey: Princeton University Press, 1994, hlm. 308.

16 Neville M. Goodman, International Health Organizations, hlm. 35.

17 Ibid., hlm. 35.

18 Lenore Manderson, Sickness and The State Health and Illness in Colonial Malaya, 1870-1940, Cambridge: Cambridge University Press, 1996, hlm. 38 dan 100.

19 Ibid., hlm.101.

20 Ibid., hlm. 106.

21 Ibid., hlm. 106.

22 The Straits Settlements Association ditubuhkan pada 21 Januari 1868 khusus bagi melindungi Negeri-negeri Selat daripada penggubalan undang-undang yang dilihat boleh menjejaskan kepentingannya, menggugat kedudukannya sebagai sebuah pelabuhan bebas dan menghalang kemajuan perdagangan.

23. Lenore Manderson, Sickness and The State Health and Illness, hlm. 49.

24 Lihat Straits Settlements Record Singapore National Library (SSR) (SNL), V 23, Governor's Miscellaneous Letters (out), 1824-1867, hlm 20-23 
dan C. M. Turnbull, The Straits Settlements 1826-67, Indian Presidency to Crown Colony, Singapore: Oxford University Press, 1972, hlm. 218.

25 Lenore Manderson, Sickness and The State Health and Illness, hlm. 49.

26 Ibid., hlm. 45 .

27 Ibid., hlm. 45.

28 Ibid., hlm. 127-128. Untuk maklumat lanjut tentang Sistem Kangani, lihat Sivachandralingam SundaraRaja, "Sejarah Penubuhan dan Perkembangan Tabung Pekerja India Selatan, 1907-1909: Satu Kajian Awal", Purba, Bil. 22, 2003, hlm. 41-52; J. Norman Parmer, Colonial Labour Policy and administration: A History of Labour in the Rubber Plantation Industry in Malaya, 1910-1941. New York: Locust Valley, 1960 dan Kernial Singh Sandhu, "Some Preliminary Observations of the Origins and Characteristics of Indian Migration to Malaya, 1786-1957", Intisari, Jil. 3, No. 4, hlm. 22-40.

29 Lihat Noraini Mohamed Hassan, Penyakit Tropika di Negeri-negeri Melayu Bersekutu, 1896-1914, Kuala Lumpur: Penerbit Universiti Malaya, 2008.

3: Lenore Manderson, Sickness and The State Health and Illness, hlm. 30.

31 J. Norman Parmer, "Estate Workers' Health in the Federated Malay States in the 1920s", dalam Peter J. Rimmer \& Lisa M. Allen, The Underside of Malaysian History: Pullers, Prostitutions, Plantation Workers, Singapore: Singapore University Press, 1990, hlm. 179.

32 Lenore Manderson, Sickness and The State Health and Illness, hlm. 130.

3.3 Enakmen Imigrasi Buruh India Selangor, 1884 terkandung dalam Selangor Secretariat File 858/1887.

34 Enakmen Imigrasi Buruh India Selangor, 1884, seksyen 26, Bahagian IV.

$35 \quad$ Ibid., hlm. 129.

36. Lihat Perak Government Gazette, Vol. IV, No. 2, October 23, 1891, hlm. 1016; Warta Kerajaan Perak, Jil. 2, Bil. 2, Februari 28, 1898, hlm. 38. Arkib Negara Malaysia Cawangan Perak. Lihat juga J. M. Gullick, Malay Society in the Late Nineteenth Century The Beginning of Change, Singapore: Oxford University Press, 1987, nota 13, hlm. 259 dan 271.

37 Lihat J. R. Logan, "Notes at Pinang, Kedah etc.", Journal of Indian Archipelago and Eastern Asia (JIAEA), 5, 1851, hlm. 54-55.

38 Lihat W. Linehan, "A History of Pahang", JMBRAS, Vol. XIV, 2, 1936, hlm. 98.

39 J. W. W. Birch, The Joumals of J. W. W. Birch First British Resident to Perak 1874-1875, P. L. Burns (ed.), Kuala Lumpur: Oxford University Press, 1976, hlm. 82.

40 T. Braddell, "Notes of a Trip to the Interior from Malacca", IIAEA, 7 , 1853, hlm. 98-99 dan J. M. Gullick, Malay Society, hlm. 259.

ti Lihat W. W. Skeat \& F. F. Laidlaw, "The Cambridge University Expedition to Parts of the Malay Peninsula 1899-1900: Personal Accounts", JMBRAS, Vol. XXVI, 4, 1953, him. 41-43 dan Emily Sadka, (ed.), "The Journal of Sir Hugh Low, Perak, 1877", JMBRAS, Vol. XXVI, 4, 1954, hlm. 60 . 
42 Lenore Manderson, Sickness and The State Health and Illness, hlm. 48.

4.3 Ibid., hlm. 49-50.

44 Thomas Braddell pernah dilantik sebagai Peguam Negara Singapura yang pertama antara tahun 1867"1883. Beliau banyak menerbitkan penulisan sejarah di dalam JIAEA pada sekitar tahun 1850-an.

45 'Putchoh' merujuk kepada tunas pokok buluh atau tumbuhan lain yang digunakan bagi tujuan perubatan. Lihat J. M. Gullick, Malay Society, nota 9, hlm. 259 dan 271.

46 T. Braddell, "Notes of a Trip to the Interior from Malacca", JIAEA, 7, 1853, hlm. 98-99.

47 Ibid., hlm. 98-99 dan J. M. Gullick, Malay Society, nota 9, hlm. 259 dan 271.

${ }_{48}$ Lihat "Small-pox Disturbances in Krian", The Malay Mail, 23 Mac 1899 dan J. M. Gullick, Malay Society, hlm. 260.

t9 Lenore Manderson, Sickness and The State Health and Illness, hlm. 50.

50 Sebuah kampung yang terletak di antara Bukit Gantang dan Kuala Kangsar.

51 Lihat Emily Sadka, "The Journal of Sir Hugh Low", hlm. 41 dan 61-62.

52 Perak Government Gazette, Vol. X, No. 5, February 26, 1897, hlm. 119-120.

53 Lihat Perak Government Gazette, Vol. X, No. 5, February 26, 1897, hlm. $119^{\prime \prime} 120$.

5+ Lihat Emily Sadka, "The Journal of Sir Hugh Low", hlm. 80.

55 Lenore Manderson, Sickness and The State Health and Illness, hlm. 52. Enakmen Kuarantin dan Pencegahan Penyakit, 1903 terkandung dalam Selangor Secretariat 1046/1911.

56 Lenore Manderson, Sickness and The State Health and Illness, hlm. 52.

57 Pulau Kamaran mempunyai keluasan kira-kira 11 batu panjang dan antara dua ke tiga batu lebar. Sebahagian besar pulau ini dilitupi batu batan keras dan sedikit kawasan berpasir yang membolehkan pohon kurma hidup. Tanahnya agak rendah, namun di bahagian selatan terdapat tanah tinggi yang membentuk bukit-bukit kecil. Bahagian utaranya dilitupi kawasan berpaya dan hutan. Menurut Roff, pulau berkenaan tidak berpenghuni tetapi Playfair mencatatkan bahawa sekitar tahun 1857 terdapat tujuh buah perkampungan nelayan yang mana kebanyakan penduduknya terlibat dengan penternakan penyu dan mutiara. Kamaran merupakan sebuah tapak yang sesuai dijadikan pusat bagi kuasa maritim yang berhasrat menguasai kedua-dua pintu masuk ke Laut Merah atau bahagian selatan Semenanjung Tanah Arab. Alfonso d'Albuquerque pernah menguasainya pada awal abad ke-16 sebelum diambil alih oleh Husayn al-Kurdi dan Salman Pasha. Daulah Uthmaniyah menggunakan pulau tersebut pada tahun 1538 dalam usaha menakluki Yaman sebelum diusir oleh Imam-imam Zaydi pada tahun 1636. Kamaran juga pernah menjadi rebutan di antara puak Wahhabi dan Perancis. Walau bagaimanapun, hasrat tersebut telah dimusnahkan oleh British yang menguasai Aden dalam tahun 1839. Daulah Uthmaniyah kembali menguasai Yaman dan Kamaran pada tahun 1849. Lihat W. R. Roff, "Sanitation and Security: The Imperial 
Powers and the Nineteenth Century Hajj", Arabian Studies, Vol. VI, 1982, hlm. 153; R. L. Playfair, A History of Arabia Felix or Yemen, Amsterdam: Philo Press, 1970, hlm. 2 dan F. E. Peters, The Hajj The Muslim Pilgrimage, hlm. 314.

58 "The Muslim Pilgrim Ordinance 1951, dalam Federal Ordinances and State and Settlement Wnactments for 1951, Kuala Lumpur: Government Printing Office, 1952. Ordinan ini juga terdapat dalam Selangor Secretariat 1686/1951 dan SUK Pulau Pinang 1950-51, 1080/51.

59 Lihat Perak Government Gazette, Vol. X, No. 5, February 26, 1897. dan Perak Government Gazette Extraordinary, Vol. XII, No. 6, February 27, 1899 dan Vol. XII, No. 7, March 6, 1899. Lihat juga Moshe Yegar, Islam and Islamic Institutions in British Malaya, Policies and Implementation, Jerusalem: The Magnes Press, 1979, hlm. 227-228.

60 Perak Government Gazette, Vol. X, No. 5, February 26, 1897.

61 The Perak Government Gazette, Vol. X, No. 6, March 12, 1897, hlm. 152.

62 Ibid., hlm. 153 dan Negri Sembilan Government Gazette, Vol. 11, No. 9, March 26, 1897, hlm. 91. Persidangan Kesihatan Antarabangsa 1926, Bahagian III, Seksyen IV hanya mensyaratkan kapal bebas penyakit menurunkan penumpang dan menjalankan proses penyahjangkitan kuman ke atas barangan individu sekiranya beberapa perkara tidak dipatuhi, iaitu, i) kesemua jemaah haji di atas kapal terpelihara daripada kolera dan cacar, ii) peruntukan yang ditetapkan persidangan dipatuhi dengan tegas dan iii) tiada sebab meragui pengakuan kapten dan pegawai perubatan kapal mengenai ketiadaan sebarang kes kolera, bubon atau cacar. Lihat juga FO 371/67509D, "Provisions of International Sanitary Convention, 1926, Part III", dalam Records of The Hajj. A Documentary History of the Pilgrimage to Mecca (RoTH), London: Archive International Group, Archive Edition, 1993, Vol. 9, hlm. 579.

63 The Perak Government Gazette, Vol. X, No. 6, March 12, 1897, hlm. 153 dan Negri Sembilan Government Gazette, Vol. 11, No. 9, March 26, 1897, hlm. 91. Persidangan Kesihatan Antarabangsa 1926 menetapkan bahawa proses penyahjangkitan yang dijalankan tidak melebihi tempoh 48 jam. Sekiranya tiada sebarang kes atau kes disyaki kolera, jemaah haji akan segera dinaikkan ke kapal dan belayar ke Jeddah. Lihat juga Foreign Office (FO) 371/67509D, "Provisions of International Sanitary Convention, 1926, Part III", dalam RoTH, Vol. 9, hlm. 579.

64 The Perak Government Gazette, Vol. X, No. 6, March 12, 1897, hlm. 153155 dan Negri Sembilan Government Gazette, Vol. 1l, No. 9, Mac 26, 1897, hlm. 91-92.

65 Lihat FO 371/67509D, "Provisions of International Sanitary Convention, 1926, Part 1II", dalam RoTH, Vol. 9, hlm. 580.

66 Persidangan berkenaan turut dihadiri oleh Jawatankuasa Kod dan Isyarat Antarabangsa, E.W. Travis dan Kapten Pelle-Desforges.

67 Lihat High Comissioner Office Federated Malay States (HCO) (FMS) 1925-1935, S136/29, "Report by the British Representative on the work of recent Sessions of the Office International d'Hygiene Publique, Paris and of the Health Committee of the League of Nations" 
68 Ibid dan HCO (FMS) 1925-1935, S1270/30, "Report of Quarantine Commission on Medical and Quarantine Sections of the International Code of Signals".

69 HCO (FMS) 1925-1935, S1270/30, "Report of Quarantine Commission". 70. Lihat The Perak Government Gazette, Vol. X, No. 5, February 26, 1897, hlm. 116-117.

71 Lihat Zainal Abidin Abd. Wahid, Yusof Ibrahim \& Mohd. Amin Hasan, Sejarah Perkembangan Tabung Haji Malaysia 30 Tahun, Kuala Lumpur: Jabatan Perdana Menteri, 1993, hlm. 76.

72 Temu bual dengan Hajah Umi Kulsom binti Kulop Mamat yang menunaikan ibadah haji pada tahun 1927 dan 1936. Temu bual pada 25 Mei 2005, di Batu 18, Padang Rengas, Perak. 